up to two years in prison, while those guilty of breaching the interdictions on practice and research should be liable to ten years in prison. Because the authority's work must command public confidence, the penalty for breaching confidentiality should be greater.

These and other issues require careful consideration in the months ahead. Let us hope that they are not too much confused by the side-issue of abortion. The Royal Society (among others) hopes that the issues can be kept quite separate, but is likely to be disappointed. For one thing, the implication that embryos older than 14 days deserve special respect is certain to fire the ambitions of those who believe that much older fetuses are at present held in scant regard. For another, because one of the most cogent arguments for allowing embryo research is that of diagnosing genetic defects before the transfer of embryos to a uterus, so avoiding abortions at a later stage, those who hold to the extreme position in anti-abortion doctrine that no interference with the lottery of human reproduction is allowable can hardly be completely silenced.

\section{Priority on HIV}

A US newspaper has raised questions about the discovery of the virus responsible for AIDS that compel explanation.

WHo first discovered the virus responsible for AIDS which is now called HIV (for human immunodeficiency virus)? At least in the United States, most people would answer "Dr Robert Gallo", referring to the head of the US National Cancer Institute's Laboratory of Tumor Cell Biology. Others, of course, will give a more sophisticated reply, saying "Gallo and Montagnier" - the second a reference to the researcher at the Institut Pasteur in Paris who is known, among many other things, as the inventor of the diagnostic test for HIV over which the Pasteur launched a patent suit against the US government in 1985. The case was eventually settled out of court in April 1987 by an agreement between the then US President Ronald Reagan and the then French prime minister, Jacques Chirac, who agreed that the battle against AIDS is too important to be marred by disputes over patents, and who decided (among other things) to use part of the royalties in dispute for supporting research in the field.

Yet the acrimony generated by that dispute and its antecedents is curiously persistent. Its latest manifestations is the appearence in the Chicago Tribune for 19 November of a gripping sixteen-page report by journalist John Crewdson of his investigations of the circumstances leading to the recognition that HIV is the cause of AIDS. Crewdson has discovered and recounts the circumstances leading to the various publications by Gallo and Montagnier in the period up to 1987 which, so far as they affect this journal directly, are correct. (He might nevertheless have told his readers what he had been told explicitly that the decision not to publish Montagnier's nucleotide sequence of HIV as well as Gallo's, which arrived first, was prompted by a wish not to publish the same sequence twice. Ironically, for Nature, the similarity has fuelled much of the later controversy.) The general tenor of his report is that Gallo has been given too much credit, and Montagnier too little.

Gallo and his associates will not be amused. Gallo may at this stage kick himself for not having collaborated with Crewdson after a first telephone conversation, so allowing what may be a one-sided account of various incidents to colour the report. It is always difficult for professional people to judge how much time - it does take endless time - they should invest in answering the questions of investigative reporters. Gallo's decision may well have been influenced by the agreement already reached between the French and the US governments, which included a chronology of the events leading to the identification of HIV drawn up jointly by him and Montangier and an agreement that neither would further comment on past history. Did that not bury the priority dispute? he may well have said.

Sadly, Crewdson's report is forceful, or at least prominent, enough to resurrect the controversy, which is damaging not only for the reputation of science but for the chief participants, Montagnier as well as Gallo. Yet the report is at once so wide-ranging and so particular that nobody could easily respond to it. Gallo, the one most directly attacked, would nevertheless do well to say something by way of refutation, most tellingly by dealing with some of the particular points that Crewdson raises. There is, for example, the letter from Gallo and several of his associates published in Nature in May 1986 (not April, as Crewdson avers) which shows an electron micrograph containing now unmistakable HIV particles budding from the white blood cells of a sample provided (from a Paris hospital) in February 1983 (see Nature, 321, 119; 1986). The burden of the letter, headed "First isolation of HTLV-III" (Gallo's name, chosen later, for HIV), was that a novel virus had been recognized at the National Cancer Institute at least by the first half of 1983, and specifically before Montagnier's first sample reached Bethesda in September that year. But Crewdson claims that Gallo did not recognize the presence of a novel virus until much later. Gallo says that Crewdson's account is incorrect, giving chapter and verse for his belief. Luckily, with outside collaborators involved, it is an issue that can be checked. It would be helpful if it were.

Montagnier also has a part to play, if only as a party to the agreed chronology of the events. Crewdson's meanest charge is that the two men have struck a truce so as the better to be able to share a Nobel prize one of these days. If that were so, it would be disgraceful, but the charge cannot be convincingly denied. Even a joint declaration of innocence could be interpreted as proof positive. Yet both must know by now that between 1983 and 1985 they were engaged in one of the most exciting and successful discoveries of this decade. Cannot they jointly find a way of making sure that this episode is not soured by a priority dispute waged by others than themselves?

NATURE $\cdot$ VOL $342 \cdot 30$ NOVEMBER 1989 